\title{
Figure-S4 (Pons)
}

A In control cells, EGF is no longer detected in early endosomes after $\mathbf{5 0} \mathrm{min}$
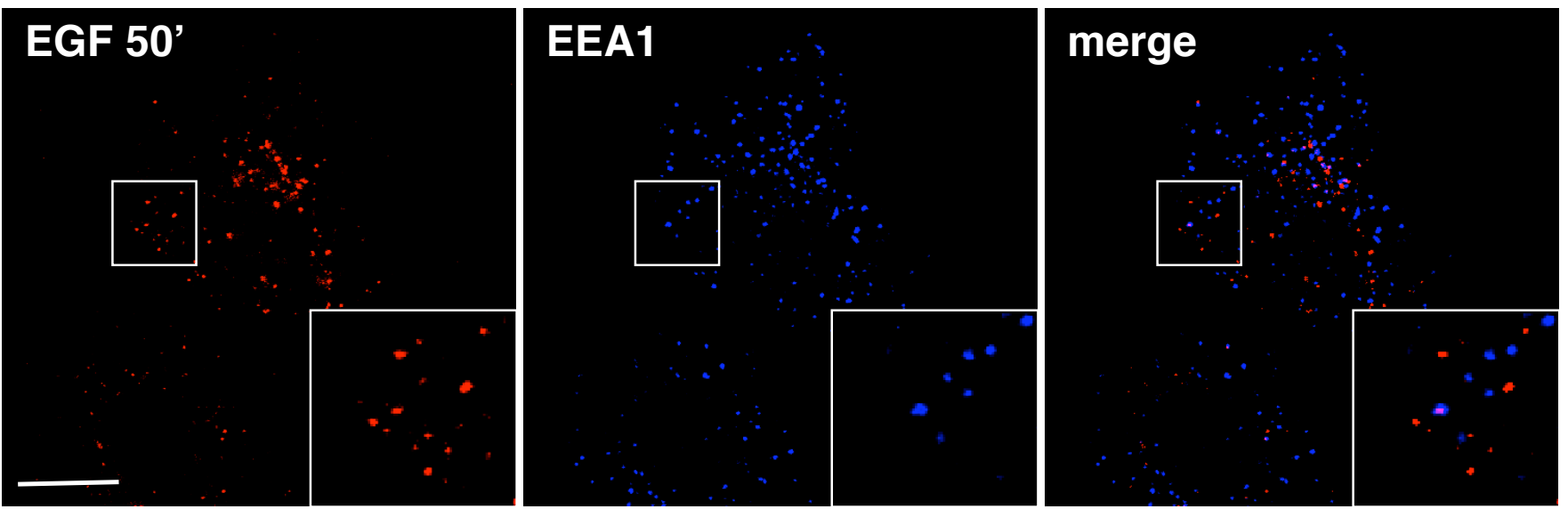

B In control cells, dextran reaches Lamp1-positive late endosomes

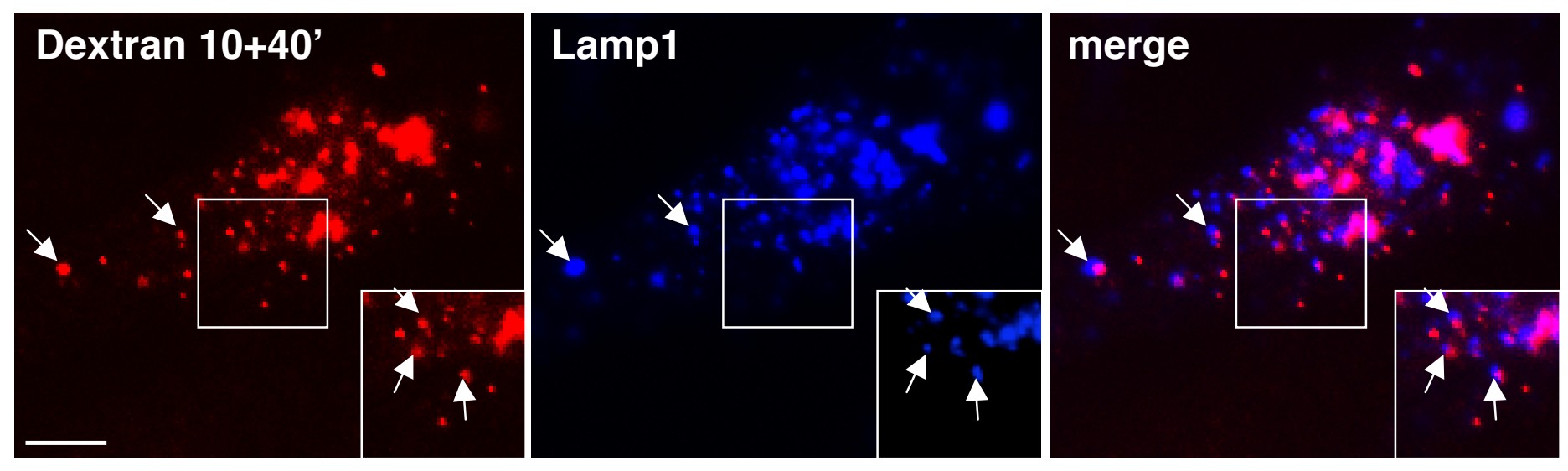

C In control cells, Shiga toxin B-subunit reaches the Rab6-positive Golgi apparatus

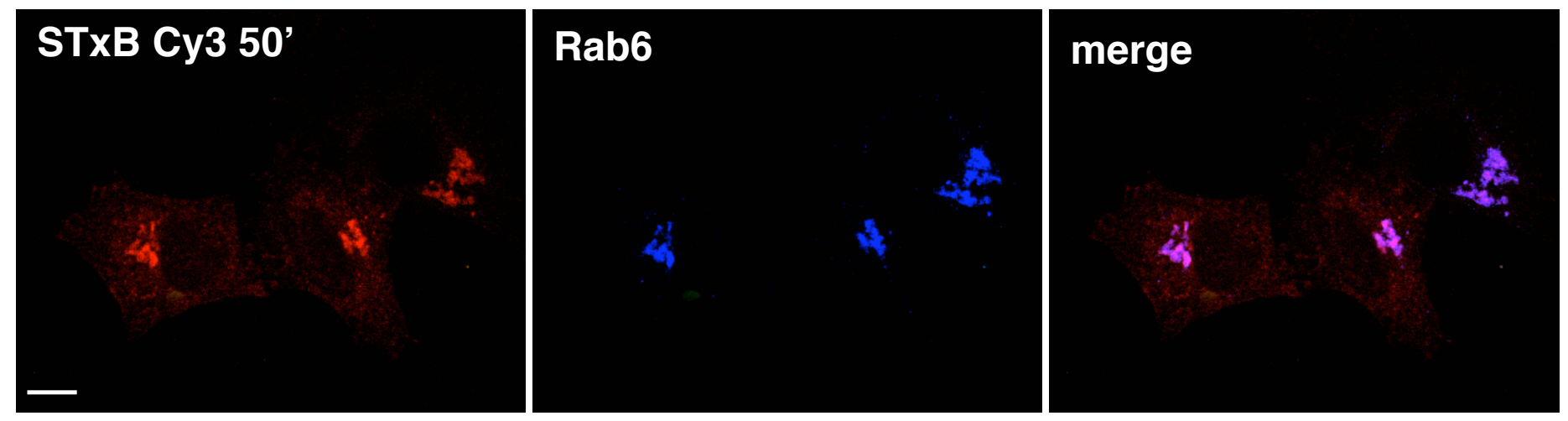

